\title{
Zoltán Kodály's Visit to Santa Barbara and the Premieres of the Psalmus Hungaricus and the Symphony in America
}

\author{
Melinda BerLÁsz \\ Institute of Musicology \\ Research Centre for the Humanities \\ Hungarian Academy of Sciences \\ Táncsics Mihály u. 7, H-1014 Budapest, Hungary \\ E-mail: melinda.berlasz@btk.mta.hu
}

(Received: September 2016; accepted: November 2016)

\begin{abstract}
The article focuses on a particular station of Zoltán Kodály's 1966 American tour, the fortnight spent in Santa Barbara, California in August 1966, during which he gave a televised interview to Ernő Dániel, chaired the conference "The Role of Music in Education: A Conference with Zoltán Kodály" held at the University of California, Santa Barbara, and attended a concert organized in his honor. Based on her research conducted on the spot in 1994 as well as on sources from the estate of Ernő Dániel, the paper also reconstructs the history of the premieres in California during the early 1960s of Psalmus Hungaricus (Santa Barbara, 1961) and the Symphony (Santa Barbara and Los Angeles, 1963). The article also surveys the career of Ernö Dániel, an alumnus of the Budapest Music Academy, in America (1949-1977)
\end{abstract}

Keywords: Zoltán Kodály, Ernő Dániel, Psalmus Hungaricus, Symphony, Missa brevis

\section{In memory of Ernö Dániel and his wife Katinka Scipiades}

Kodály's 1966 visit in Canada and the United States of America, beset with a series of celebrations, was certainly one of the most eventful and joyous periods during his last year of life. "We were there for three months," he began one of his travel accounts. ${ }^{1}$ The trip lasted from July 4 (departure) to September 29 (arrival

1. Zoltán Kodály, "Amerikai tapasztalatok. Nyilatkozat" [American experiences. A statement], in Zoltán Kodály, Visszatekintés, vol 3: Hátrahagyott írások, beszédek, nyilatkozatok [In Retrospect, vol. 3. Posthumous Writings, Speeches, and Statements], ed. Ferenc Bónis (Budapest: Argumentum, 2007), 216. 
back home). ${ }^{2}$ Another statement of his, back in Budapest, reveals the primary goal and major events of the voyage:

I was invited by several universities to speak about our teaching method which they know more and more about thanks to our foreign guests. ... There is a growing interest in it, and that was why I received an invitation first from Toronto, Canada, ${ }^{3}$ then from further five universities in the United States, giving me the opportunity to speak about our methods. ${ }^{4}$

One of the five universities was the University of California at Santa Barbara. Zoltán Kodály and his wife arrived in California from Canada; they first went to San Francisco, then to Berkeley, upon the invitation of the university there, and proceeded to Santa Barbara on the last day of July, to chair a conference organized in Kodály's honor where he also delivered a lecture.

Kodály's papers presented during the visit and his statements about the journey, as well as some pictorial documents are duly integrated in the series of Kodály's writings edited by Ferenc Bónis and in the recent Kodály picture-book also published by Bónis. ${ }^{5}$

In the present paper, I aimed to elaborate a particular station of the Kodálys' American visit, the fortnight spent in Santa Barbara in August 1966, based on the sources connected to the events, inspired by the conviction that the so-far unpublished documents - oral recollections, press coverage, concert posters, and photos - may contribute to the completion of the spiritual legacy of Kodály's oeuvre.

I came across the sources used in this paper in spring 1994 during a research trip in America, as I was examining the estates of several prominent representatives of the Hungarian musical culture living in emigration. I was also to study the work in America pursued for two and a half decades, first in Texas and later in Santa Barbara, by Ernő Dohnányi’s former student Ernő Dániel. Although in 1994 I could no longer get personal guidance from this outstanding pianist and conductor, ${ }^{6}$ by courtesy of his widow, the piano teacher Katinka Dániel, ${ }^{7}$ I had the opportunity to study their rich collection of carefully preserved documents. I learnt about the pianist Ernő Dániel's European success story in the 1940s and

2. László Eősze, Kodály Zoltán életének krónikája [Chronicle of Zoltán Kodály’s life], (Budapest: Editio Musica Budapest, ${ }^{2} 2007$ ) 306-307.

3. Kodály received an honorary degree from the Toronto University.

4. Zoltán Kodály, "A zeneoktatás társadalmi jelentőségéröl. Nyilatkozat Neszlényi Juditnak” [On the social significance of music education. A statement to Judit Neszlényi], in Visszatekintés, vol. 3, 197.

5. Ferenc Bónis, Élet-pálya: Kodály Zoltán [Life-path: Zoltán Kodály] (Budapest: Balassi Kiadó-Kodály Archívum, 2011).

6. Ernő Dániel (b. Budapest, 1918 - d. Santa Barbara, 1977) was already dead for 17 years.

7. Née Katinka Scipiades (b. Budapest, 1913 - d. Santa Barbara, 2012). 
about his international career as conductor and pianist, carried on in the United States from 1949.

One of the most accurately documented events in the Dániel estate, with the documents being kept in a separate folder, was the visit of the Kodály couple to Santa Barbara. The folder included the recording of a television conversation in English between Kodály and Ernő Dániel (see Plate 1$),{ }^{8}$ the detailed program of

Plate 1 Photograph taken on August 1, 1966 during Zoltán Kodály’s television interview conducted by Ernő Dániel at the University of California, Santa Barbara

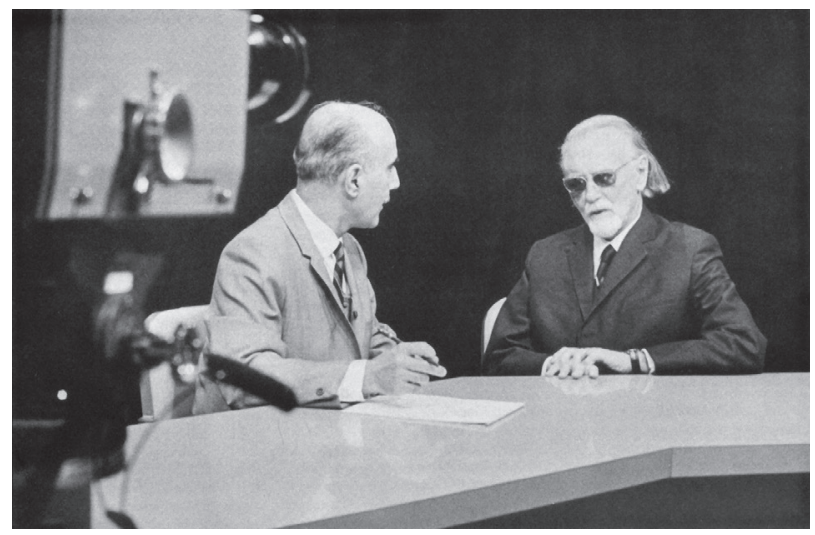

the two-day university conference on musical education entitled "The Role of Music in Education: A Conference with Zoltán Kodály," and documents of the Kodály concert organized on the same occasion (program, performers, press coverage). Beside the official schedule, the photos taken during the one week holiday the Kodálys spent in Santa Barbara testify to the convivial meetings at the Dániels' hillside residence overlooking the Pacific Ocean (Plate 2). Here belongs a second interview with Kodály made in the living room of the house by Judit Neszlényi, ${ }^{9}$ a

8. The text of the interview made on August 1, 1966 appeared both in English and Hungarian: "The Responsibilities and Opportunities of the Musician-Education," in Kodály and Education III. Zoltán Kodály in North America, ed. Richard Johnston (Willowdale, Ontario: The Avondale Press, 1986) (= Kodály Institute of Canada Monograph III), 67-74, and Zoltán Kodály: “A nevelök Santa Barbara-i konferenciája előtt. Nyilatkozat angol nyelven" [Before the conference of educators in Santa Barbara. Statement in English], in Visszatekintés, vol. 3, 197-201. The interview was recorded and broadcast by the Department of Educational Television, University of California, Santa Barbara and it is available online under: https://www.youtube.com/ watch?v=NbDvjqzb924 (last accessed on October 25, 2016).

9. The second interview, made on August 4 upon Judit Neszlényi's initiative for the Los Angeles Hungarian radio station KMAX, was released in English twice: Judith Nesleny, "Conversation with Zoltán Kodály August 1966," Bulletin of International Kodály Society 7/2 (1982), 6-10, and "Conversation with Judit Nesleny," in Kodály and Education III., 76-83. 
Plate 2 Photograph of Ernő Dániel's home in Crestline Drive, Santa Barbara From right to left: Ernő Dániel, his mother in law and his wife Katinka Dániel ${ }^{10}$

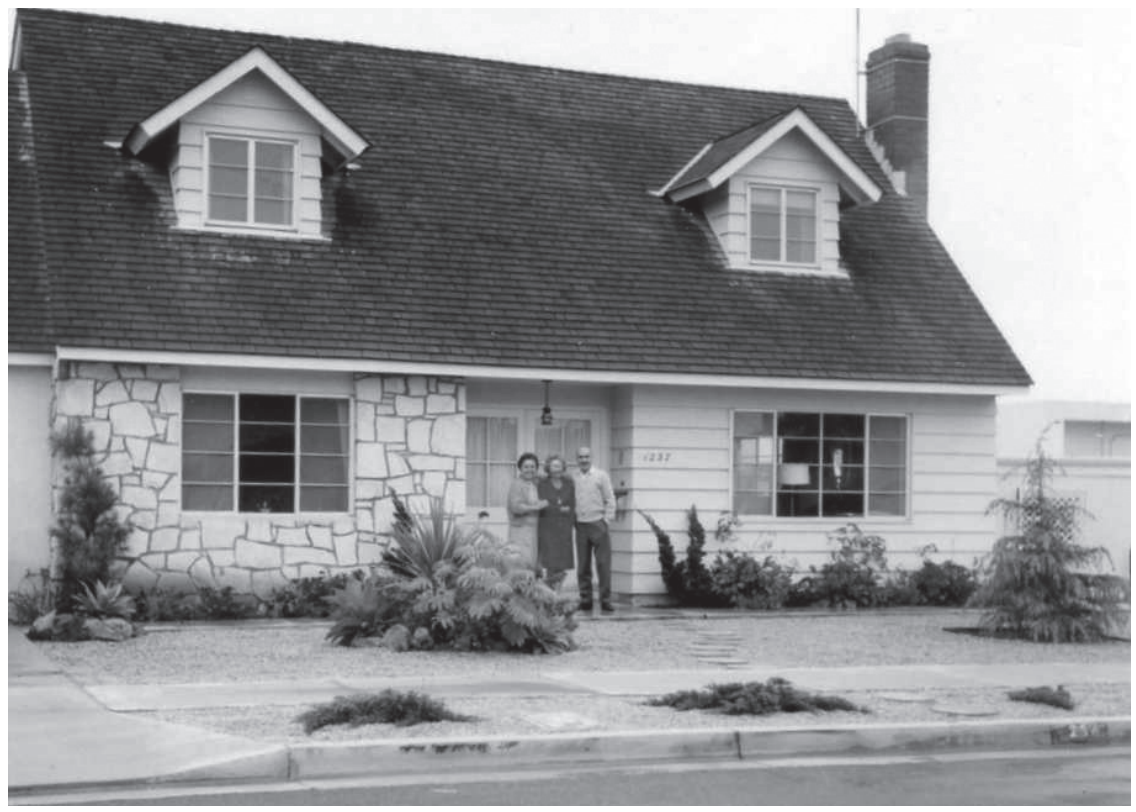

pianist of Hungarian birth who had come to visit from Los Angeles. ${ }^{11}$ In addition to the leisure days spent in the Dániels' home, there were meetings with artists (Plate 3$)^{12}$ evidenced by oral and written statements of the Dániels ${ }^{13}$ and by several photos giving the impression of memorable experiences. ${ }^{14}$

10. The photo was put at my disposal by Alexa Dániel Mrs Lynn Maland, for which I herewith thank her again.

11. Pianist Judit Neszlényi (Pfeiffer) was a student of the Budapest Music Academy who emigrated to the United States in 1956. During her studies in Budapest she attended Kodály's folk music classes. When she made her interview with Kodály in 1966, he remembered Neszlényi's singing in class. She carried on extensive activity in Los Angeles at the KMAX radio and organized several Liszt piano competitions, most recently the contest in 2014. She premiered Kodály's Dances of Marosszék in California at the opening of the Norton Simon Museum in Pasadena in 1971.

12. We know from Judit Neszlényi that on the day after the conference, on 4 August, Mrs Dániel invited to dinner the participants of the Kodály concert including Ferenc Roth, leader of the Roth quartet, the speakers of the conference, and Kodály's former student, composer Jenő (Eugene) Zádor.

13. On the fifth anniversary of Kodály’s death Ernö Dániel briefly reminisced about Kodály’s Santa Barbara visit: "Hódolat és tisztelet. (Kodály-emlékek)" [Homage and respect. (Memories of Kodály)], Muzsika, 15/12 (December 1972), 13.

14. In his Kodály picture-book, Ferenc Bónis presents a photo of the Kodály couple, surrounded by a group of the Hungarian émigré musicians and artists living in California. See image 843 "Kaliforniában," [In California] in Bónis, Élet-pálya. With the help of Judit Neszlényi, I was able to identify the persons on the photograph. In the first row from left to right one can see: Katinka Dániel, Feri Roth, Ernő Dániel, Zoltán Kodály and his wife, Éva Szörényi, Sándor Bory; in the second row: Károly Héthalmi Páth, Judit Neszlényi, and Jenő Zádor. 
Plate 3 Dinner guests invited by Mrs Dániel

[in a clockwise direction:] Ernő Dániel, dr. W.C. Harshorn, dr. G.H. Kyme, Jenő Zádor, [unknown person] and Zoltán Kodály

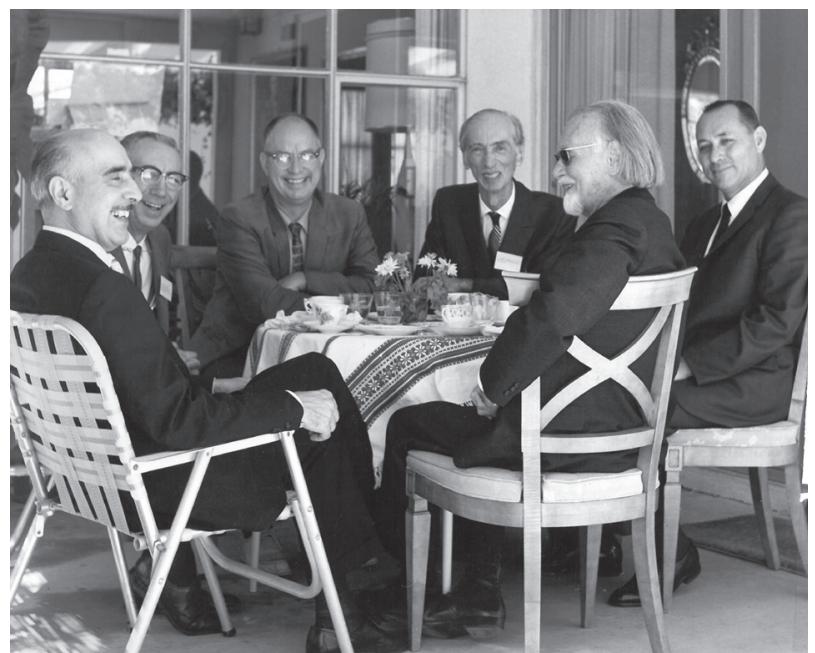

The present publication of the Kodály documents in the Dániel estate was motivated by a dual goal: first and foremost, to introduce so-far unpublished oral and written material on Kodály from a new source group, which enriches with several new details the reception history of the Kodály couple's America tour. The second goal - in accordance with the preliminary project of my research - is to review the efforts of Ernő Dániel in disseminating Hungarian music in America.

The Kodály sources in the Dániel estate made it clear to me that Ernő Dániel, the head of the musical faculty at the University of California, Santa Barbara, had a salient role in Kodály's American tour from providing the initiative through the planning to the final realization. The two-day conference and the Kodály concert were enthusiastically supported by the university leaders as well as by the musical community of California.

Kodály's visit to Santa Barbara in the first two weeks of August 1966 was preceded by several Kodály premieres there during the first half of the sixties. The Kodály premieres in California led by Ernö Dániel as well as the information disseminated in connection with the performances were important prerequisites to the standing ovation with which the audience consisting of some one thousand people received Kodály in person. Since these performances have not been covered so far, I touch on the premieres of Psalmus Hungaricus and the Symphony that took place before the visit. At this point, however, another gap is to be filled: in the 
Plate 4 Photograph of conductor Ernő Dániel

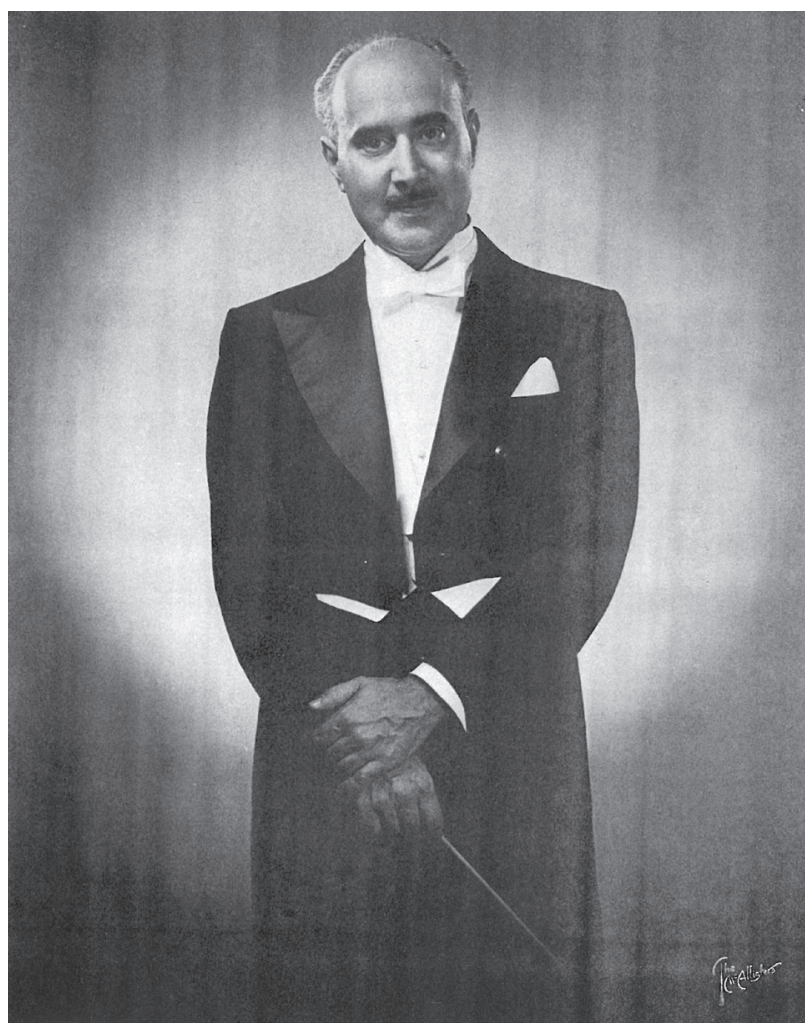

isolation behind the Iron Curtain, following World War II, almost no information could be had on the work and achievements of Hungarian émigré musicians serving Hungarian culture abroad, which has to be made up for inevitably in any publication now.

Together with Géza Anda, Gyula Károlyi, and Gizella Furka, Ernő Dániel was among the last students in Ernő Dohnányi's class of concert pianists at the Budapest Music Academy during the early 1940s. ${ }^{15}$ Dániel's playing attracted attention already during his concert tours in Austria, Italy, and Germany in the war years, his interpretations of Liszt and Beethoven in recitals and orchestral concerts ${ }^{16}$ brought him success. The promising start of his career was threatened by the communist takeover in 1948-1949. His exit visa issued in 1948 by the Ministry of Religion and Public Education was withdrawn by the newly set up Ministry

15. Dániel graduated as a concert pianist in Dohnányi’s class in 1941. All his mentioned schoolmates conducted later their artistic activity abroad as emigrants.

16. Ferenc Fricsay and Willem Mengelberg were among the conductors under whose baton Dániel performed. 
of General Education a few months later, ordering him to return immediately to Budapest, without regard to his contractual obligations for an American concert tour. ${ }^{17}$ This arbitrary treatment provoked the decision of Ernő Dániel, who was in Rome on scholarship, to emigrate: in July 1949 he headed for America instead of returning to Hungary. ${ }^{18}$

His activity in America bound him to two states: first he taught at the Midwestern University in Wichita Falls, Texas, where in 1952 he became music director and conductor of the Symphony Orchestra and from 1953 the dean of the School of the Fine Arts of the University. From there he moved to Santa Barbara, California, in 1960, where he continued working in his former areas, as a leading conductor of the Symphony Orchestra of Santa Barbara (see Plate 4) and as pianist. He reared outstanding pianists ${ }^{19}$ and chamber musicians as professor and head of department at the University, and raised the standards of the university orchestra. He entrusted this ensemble with the premiere of Kodály's Symphony.

The growing burden of administration made him quit his activity as conductor of the orchestra in 1967 and he devoted the following decade to his ambitions as a

Plate 5 Photograph of the Schönfeld-sisters in the company of the Kodály-couple, during their visit in Santa Barbara in August 1966

From left to right: Mrs. Kodály, Eleanor Schönfeld, Ernő Dániel [standing], Alice Schönfeld, and Zoltán Kodály

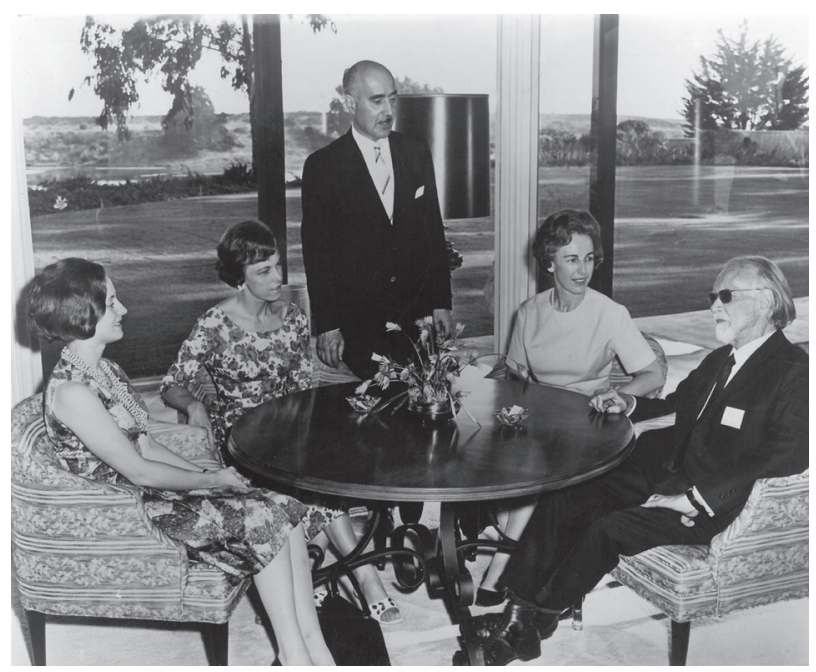

17. A copy of a letter, asking for support, written by Ernő Dániel to Ede Zathureczky, the director-general of the Music Academy (dated Rome, February 5, 1949) is extant in the Dániel estate.

18. Another letter reports that Ernő Dániel starting off for America was seen off at the station by another would-be emigré, staying in Rome on scholarship at the same time, Sándor Veress.

19. Among others, Van Cliburn as well as Albert Wasmus and Susan Hsu professed to be his students. 
soloist. In the new situation he could realize a long-cherished dream: he founded a piano trio with the Schoenfeld sisters ${ }^{20}$ living in California (Plate 5). They aimed to present the cycles of trios by the paragons of the classical music historical tradition, Mozart, Haydn, Beethoven, Schubert, and Brahms. The initiative considered as a rarity and lasting for several years elicited the appreciation of the profession: the noted Haydn scholar Karl Geiringer, then a guest professor at Santa Barbara, prophesied a great perspective for the ensemble in view of the initial results.

Dániel's artistic career had several traits in common with his former master Ernő Dohnányi's activity of piano playing and conducting at times alternately, at other times simultaneously. The periods in Dániel's career were somewhat similar to his master's: after a decade of solo performances in the 1940s he took on a dual role in the United States by adding the position of conducting as well, and in the last period he returned to solo recitals and chamber music. It was in America that Dániel acquired his conducting expertise from Pierre Monteux, George Szell and Eugene Ormandy (Plate 6). Having soon become an acknowledged conductor of American orchestras, he also became a member of the American Symphony Orchestra League and, for decades, he had a very active role in the comprehensive conductor's training program of the League, including courses organized all over America.

Dániel's Hungarian musical training was manifest in the theoretical and practical education of his American disciples and in his activity as a piano teacher, too. As regards the method of musical education, he introduced Kodály's principles, and in his piano class he mediated the tradition of the Liszt and Dohnányi School. As conductor he advocated the programming of the historical and contemporary values of Hungarian composition, and as a pianist he transmitted to the New World the Liszt tradition handed over by István Thomán and Ernő Dohnányi at the Budapest Music Academy. As the president of the American Liszt Society during the 1970s he enhanced the efficiency of this organization. He regularly included the works of Bartók, Kodály and other $20^{\text {th }}$-century Hungarian composers in his concert programs ${ }^{21}$ and on a number of his audio recordings.

\section{The premieres of Kodály works in Los Angeles and Santa Barbara in the first half of the $1960 \mathrm{~s}$}

In his pronouncements about his American tours of 1965 and 1966, evaluating the overseas interpretations of his works, Kodály stated on several occasions that "even those who were far from the language and the Hungarian culture could

20. Alice (violin) and Eleonore (cello) Schoenfeld.

21. He premiered orchestral and chamber works by Sándor Veress, János Viski, László Lajtha, Miklós Rózsa, Jenő Takács, Jenő Zádor, and others. A separate study should be devoted to his performances of the works of Kodály and Bartók. 
Plate 6 Ernő Dániel with Eugene Ormandy

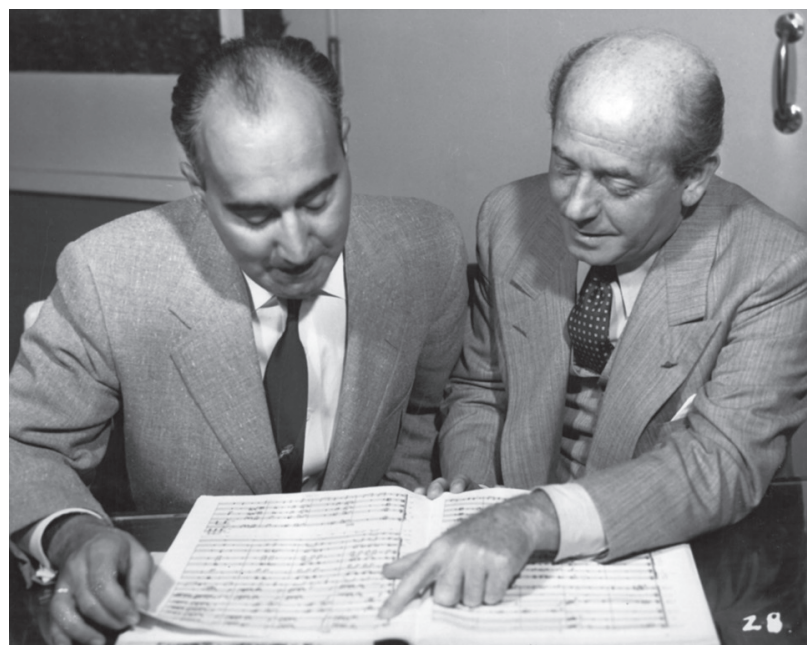

learn the right mode of performance" from the Hungarian musicians active in America. ${ }^{22}$ Ernő Dániel was one of those Hungarian musicians who was one of the models for an exemplary Kodály interpretation in America. He held separate Kodály courses for his piano students.

In the first half of the 1960s two important orchestral Kodály works, Psalmus Hungaricus and the Symphony were premiered by the Santa Barbara Symphony Orchestra. The conductor's estate includes a number of documents concerning the history of these concerts. ${ }^{23}$

Psalmus Hungaricus was performed in Santa Barbara on January 31 and February 1, 1961. Ernő Dániel's wife, Katinka Scipiades, who followed her husband to America with their two children in $1960^{24}$ after twelve years of hopeless waiting, having at long last acquired an official emigration permit upon the personal intervention of UN secretary general Dag Hammarskjöld, took with her a film on Kodály made in Budapest. This was projected as a preliminary to the Psalmus premiere in order to inform the concert audience. Ernő Dániel completed the film with explanations and his piano playing.

Just a year at the head of Santa Barbara Symphony Orchestra, Dániel could hardly have chosen a more exacting Kodály composition beset with language difficulties than the Psalm composed for orchestra, choir, and solo voice.

22. Zoltán Kodály, “Amerikai találkozások. Nyilatkozat” [Meetings in America. Statement], in Visszatekintés 3, 581.

23. During my research trip in 1994, Mrs Dániel presented the copies of the most important documents in the Dániel estate to me. I am presenting a selection of the documents of Kodály premieres relying on these sources.

24. Among the Dániels' children I owe my deepest gratitude to Alexa Dániel Mrs Lynn Maland, for her help and support for this writing. 
Plate 7 Program of the concerts conducted by Ernő Dániel on January 31, and February 1, 1961

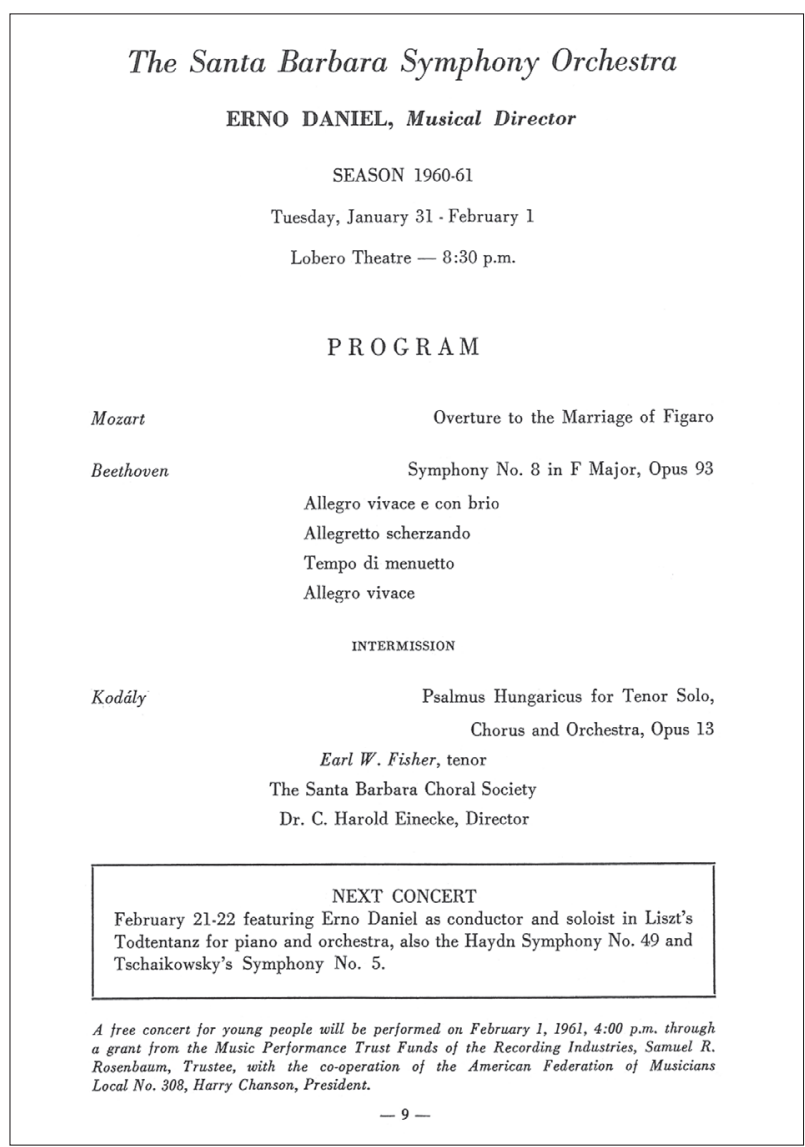

Before the Psalmus premiere several announcements were made in the Santa Barbara press. A preliminary article in a local paper informed the readers that

the Santa Barbara Choral Society, directed by Dr. C. Harold Einecke, and the Santa Barbara Symphony Orchestra will join forces this season for a major program. A performance of the "Psalmus Hungaricus" by Zoltan Kodaly, one of the great choral works, will take place ... Dr. Erno Daniel, the orchestra's permanent conductor will direct the performance which will also feature Earl W. Fisher as tenor soloist. ${ }^{25}$ 31, 1961, entitled: "Einecke, Choralists To Assist Symphony." 
The report also enlarged on the foundation of the society in 1951 and their repertoire, and touched on the studies of the noted choir master C. H. Einecke in England with Sir Adrian Boult and Ralph Vaughan Williams. Another article was devoted to Earl W. Fischer who was to interpret the tenor solo, mentioning his studies with Lotte Lehmann ${ }^{26}$ and his achievements as operatic and concert performer. ${ }^{27}$

The press preliminaries show that Dániel engaged for the Kodály premiere some of the outstanding performing artists in California. The first half of the program included Mozart's Figaro overture and Beethoven's Symphony No. 8, Kodály's Psalmus being presented after the interval (Plate 7). The audience could follow the text of the Psalmus in English on handouts distributed before the concert. ${ }^{28}$ There was a detailed and appreciative review of the premiere in the Santa Barbara News-Press on February 1.

[...] The musical work, heard here for the first time, was the "Psalmus Hungaricus" of Zoltan Kodaly - a 20th Century musical setting for the 55th Psalm of David, as translated and "expanded" by a 16th Century Hungarian pastor and poet, Michael Veg.

Dramatic impact - In a musical idiom compounded of Hungarian folk song in the six-tone modal scale, and the dissonant-consonant harmonic background of 20th Century Western music, Kodaly fashioned a score that lends dramatic impact to the impassioned words of David's angry lament and impassioned prayer, provides effective contrasts of mood and dynamics, and offers no serious hindrance to the eloquence of the solo voice. The words are given their rightful importance, and are not tortured into angular melodic lines as is done frequently by contemporary composers.

Some of the most effective writing is in the choral parts - sometimes as a unison choir offering the comments and interjections of the poet-translator, sometimes as a background chorus symbolizing the unruly, rebellious people, or the devout and righteous appealing to a merciful God.

Melodic phrases - The text of the authentic psalm is given entirely to the tenor voice, partly in recitatif on a single repeated note, but mostly in melodic phrases of archaic strength and color, rising to exciting climaxes of passionate appeal. The orchestra provides fascinating tonal texture and rhythmic support for the voices, and in the interludes sounds forth with almost barbaric dissonant outbursts, fading into poetic passages of wandering Oriental melody.

26. Lotte Lehmann (1888-1976) was a professor at the University in Santa Barbara in the last years of her life.

27. Clipping of a newspaper article without the name of the author and the press organ, prior to January 31, 1961, entitled "Fisher to Be Soloist With Symphony Here."

28. The text of Psalmus Hungaricus was translated into English by Edward Joseph Dent for the London premiere. The Universal pocket score carried the text in three languages (Hungarian, German, and English). Dent's English version was handed out to the audience at the Psalmus first night in Santa Barbara; a copy is preserved in the Dániel estate. 
Earl Fisher revealed a tenor voice of clarity, color and satisfying power in the climactic high notes, and brought both intelligence and musicianship to the task of communicating the psalmist's thought and feelings to the audience.

The choral group, sponsored by the Adult Education Center and the Choral Society, and trained by Dr. C. Harold Einecke, brought honor to itself and its leader by mastering a work of complexity and subtlety, and singing it with superb control, flexibility and precision.

Dr. Erno Daniel, musical director of the symphony conducted the entire ensemble and deserves the highest commendation for both fine musicianship and inspiring leadership. $[\ldots]^{29}$

As is known, the world premiere of Kodály's Symphony was conducted on August 16, 1961 in Luzern by Ferenc Fricsay, and the American premiere took place a few months later on January 4, 1962 in the interpretation of George Szell and the Cleveland Orchestra. The California premiere with Ernö Dániel and the Symphony Orchestra of the University of California at Santa Barbara took place on February 20, 1963 and in Los Angeles on March 24, 1963. The poster of the February performance reveals that the first performance of the Symphony was dedicated to the $80^{\text {th }}$ birthday of Kodály and that the work was to be performed by the University Symphony Orchestra consisting of young musicians instead of the professional Symphony Orchestra (Plate 8).

Compared to the Psalmus premiere, relatively little press coverage survives of the performance of the Symphony in the Campbell Hall, Santa Barbara. The only noteworthy document - a preliminary article on Kodály and the Symphony - was published on February 19 by the Santa Barbara News-Press.

This work was commissioned by the members of the Swiss Festival Orchestra and first performed at the Lucerne Festival on August 16th, 1961 under the direction of Ferenc Fricsay. It opens with a broad lyric theme in the low strings and sweeps onward, almost like the flow of the lovely Danube river which divides the capital of Hungary into two beautiful halves.

From this melodic theme the energy of the movement derives rhythmic materials that carry out the purposes of the form of the symphony. The exquisite textures of the muted violins in the second movement are counterpoised against chromatic French horn chords that provide a feeling of impermanence which in turn is relaxed by interesting melodies in the woodwinds. The final movement is filled with a pulsating rhythm that recalls folk dance idioms of romantic flavor.

29. Ronald D. Scofield, "Symphony-Chorus Work Dramatic," Santa Barbara News-Press, Wednesday Evening, Feb. 1, 1961. 
Plate 8 Program of the concert conducted by Ernő Dániel on February 20, 1963



As one examines the score, he is impressed with the lack of contemporaneousness in the materials. Whether this is reflective of the personality of the aged composer, or restrictions which are imposed by Iron Curtain officials, is a question this reporter cannot answer. It might be a mixture of the two, although the plastic arts from Hungary in recent international exhibitions which we have witnessed do not indicate restrictions of this nature to modern approach and ideas. Kodaly's life has been closely associated with the musical awakening of Hungary for he was vitally interested in the folk-song collections which he and Bartok and other Hungarian composers developed in the early part of this century. Perhaps his greatest work has been the "Psalmus Hungaricus" Opus 13, on the text of the Sixteenth Century Hungarian poet Michael Veg, of Kecskemet where Kodaly was born. His humorous opera, "Hary Janos" dates from 1926 and the music has been performed in orchestral suites by the New York Philharmonic Symphony Orchestra.

The three strands that make up the materials with which he works are the national elements of Hungarian folk-music, a lyric gift for melody which is 
inherent in Kodaly's personality, and a leaning to the picturesque which shows up more effectively in his dramatic music. When the German expressionists were developing violent reaction to the romantic excesses of Wagner, Kodaly remained a true tone-poet, whose lyrical feeling was never allowed to run to excess. ${ }^{30}$

However, the Symphony's second performance in Los Angeles was followed by several reviews. The organizer of the concert, actress Lilly Erdődy, wished to highlight the rich spectrum of genres in Kodály's oeuvre in the program. The program included songs, piano, chamber and choral pieces, the Symphony for orchestra and excerpts from Háry János to represent the stage works with selected songs and dance scenes. Lilly Erdődy drew on noted representatives of Hungarian musicians and dancers living in South California. (A letter of invitation and the correspondence on rehearsal possibilities before the concert can also be found in Ernő Dániel's estate, see Appendix 1). It was becoming of the festive occasion to request famous Hungarian personalities to be the patrons of the event: next to the guest of honor, Professor Theodore von Karman, actor Oszkár Beregi, opera singer Kálmán Pataki, film makers George Pál and Joe Pasternak, and composers Miklós Rózsa and Jenő Zádor were also named as patrons of the concert.

Kodály was also informed of the planned festive evening, and he sent a message of greeting and admonition to the Hungarians of California. In the message, he expressed his concern that the Hungarians in American emigration devoted little attention to the preservation of their literary legacy. The message made a great stir among émigré Hungarians and it was published in the Hungarian-language Szabadság of Los Angeles (Appendix 2). ${ }^{31}$

The leaflets in Hungarian and English also informed of the charitable goal of the concert: contribution to the funds of the Music Center under construction in Los Angeles (see Plate 9). The list of names on the program sheet (Plate 10) is practically a roll-call of the Hungarian musicians and artists living in California in 1966. They included composer Miklós Rózsa, who undertook to introduce the concert, the cellist Gábor Rejtő and pianist Alice Rejtö, the Roth quartet, Ernő Dániel (as conductor and pianist), singers Sándor Bory, Ferenc Várkonyi, and

30. N.d., "Daniel Will Direct Tribute To Former Colleague Kodaly," Santa Barbara News-Press, Tuesday Evening, Feb. 19, 1963.

31. It must be noted that two years later, on May 12, 1965 Lilly Erdődy put down another declaration by Zoltán Kodály under the title "Üzenet az amerikai magyaroknak" [Message to the Hungarians in America], first published in Magyar Hirek 18/22 (1965) and later re-printed in Visszatekintés 3, 438. This text is not identical with the message sent to Los Angeles, entitled “Kodály Zoltán üzenete” [Zoltán Kodály's message]. As his writings reveal, Kodály was constantly preoccupied with the deterioration of the Hungarian language in emigration. Visszatekintés includes four statements on the subject with different titles between 1961 and 1965. Kodály reflected upon the concert held in Los Angeles on March 24, 1963 in another written message to the Hungarians there sent via the organizers, which appeared in the local Szabadság. The clipping from the Los Angeles newspaper does not have a date; it is presumed to have been printed in the days around the concert on 24 March. Kodály's greeting and admonition can be viewed as a so-far unpublished source on the subject. 
Plate 9 Leaflet advertising the Kodály concert of March 24, 1963

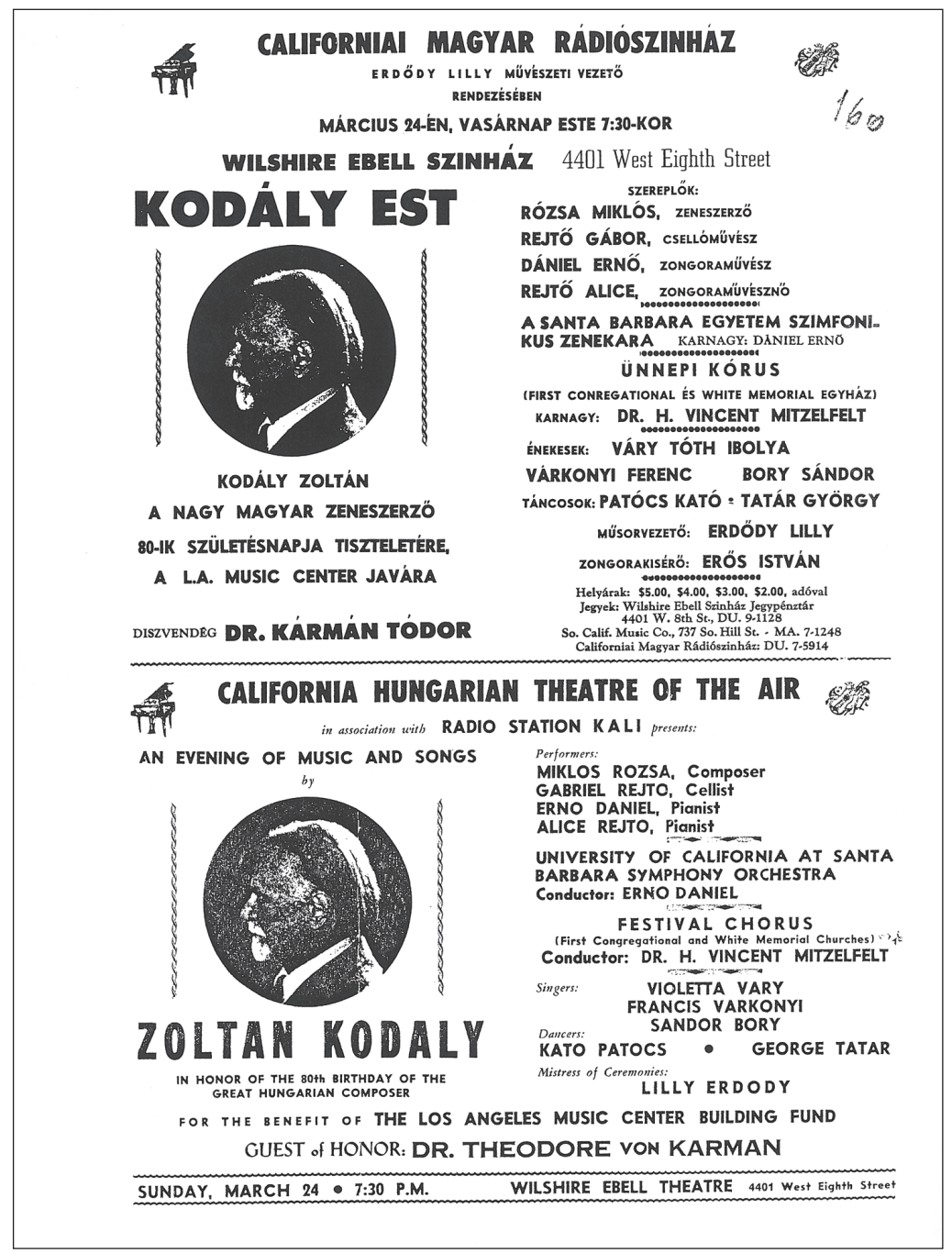

Violetta Váry as well as the Tatár-Patócs dancing duo. ${ }^{32}$ Compositions requiring larger ensembles - the choruses and the Symphony - were naturally performed by non-Hungarian musicians. The three choral works by Kodály indicated on the program were performed by the Festive Chorus of the First Congregational and White Memorial Churches conducted by H. Vincent Mitzelfelt. The Symphony,

32. According to a review the Second String Quartet indicated in the program as to have been performed by the Roth quartet was omitted. 
Plate 10 Full program with names of the performers at the Kodály evening of March 24, 1963

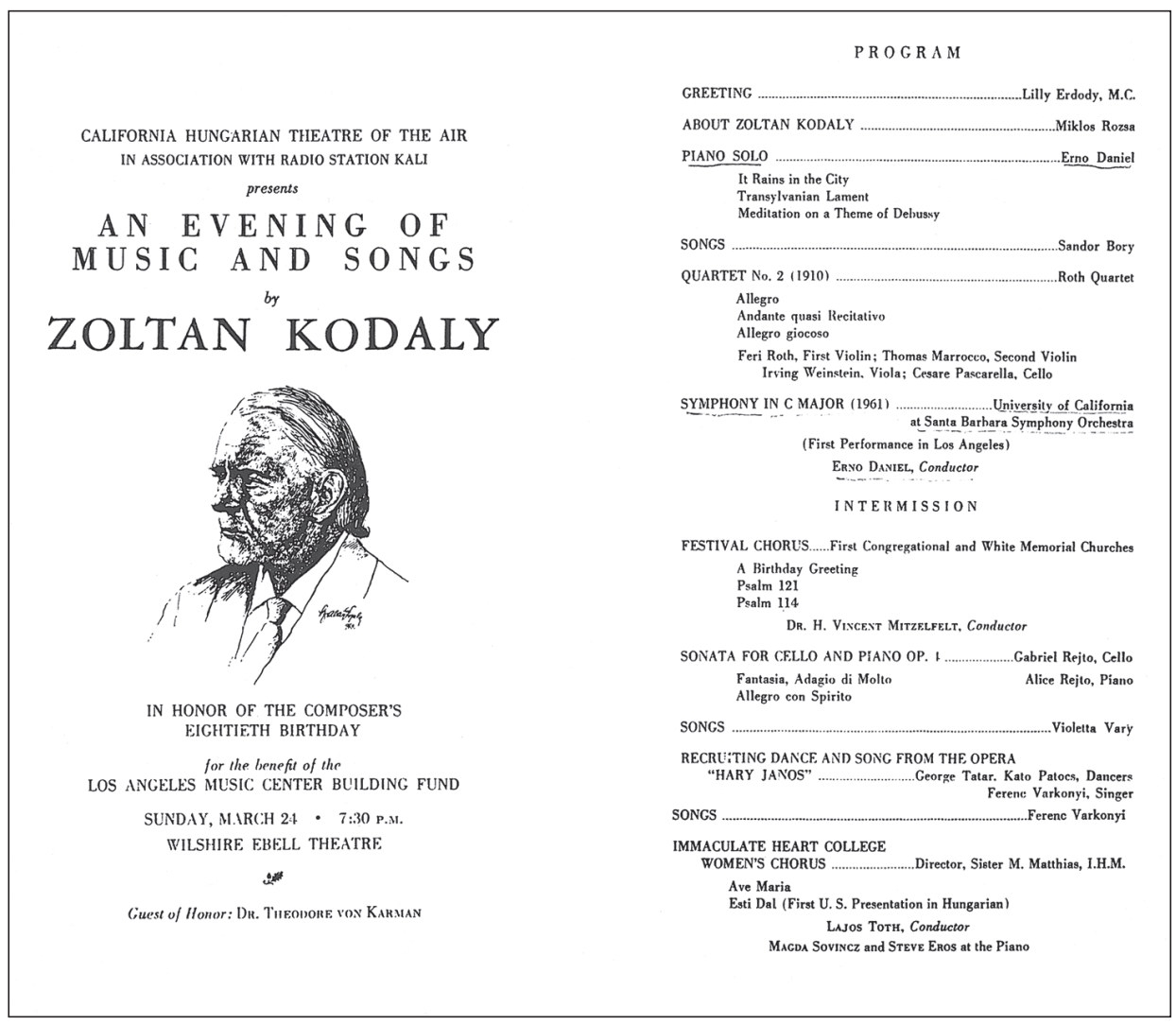

as mentioned earlier, was played by the University of California at Santa Barbara Symphony Orchestra. The program sheet also included Kodály's choruses Esti dal [Evening song] and Ave Maria sung by the Immaculate Heart College Women's Chorus led by chorus conductor Lajos Tóth. ${ }^{33}$

Two advertisements, four reviews, and a professional criticism were published about the Kodály concert, jointly organized by the California Hungarian Theatre of the Air and the radio station KALI. It is worthy of note that the renowned music critic Albert Goldberg wrote favorably in the March $26^{\text {th }}$ issue of the Los Angeles Times about the "long and varied program," the compositions, and the outstanding performers. The only work that elicited a negative opinion was the Symphony. 
Tepid Symphony - The largest and latest work on the program was the first local performance of the Symphony in C Major, written in 1961. It is a tepid and not very distinguished composition, folkish in manner, reminiscent of Smetana, Dvorak and other composers of that ilk and much like the music being written by Soviet composers to conform to the Communist demands for simplicity and easy comprehensibility.

The performance by the University of California at Santa Barbara Symphony Orchestra under the direction of Erno Daniel was cautious but surprisingly good in the string and brass departments and seemed to reveal about all that was necessary in the way of color and articulation. ${ }^{34}$

The section in Goldberg's review dealing with Kodály's composition, subtitled "Tepid Symphony," is a historical document of the American outlook and culture political stance in the 1960 s, with its tendentious perspective and lack of information concerning Kodály's conception.

The rest of the press sources judged the concert an absolute success. A Hungarian report has also been preserved among the articles. ${ }^{35}$

Next to the printed documents, a photograph of the performers and the conductor Ernő Dániel was preserved in the Dániel estate (Plate 11).

Among the many oral communications and written documents on the Kodálys' sojourn in Santa Barbara, the memories of Katinka Dániel can be taken for the most detailed and authentic sources of the event. At the time of my research nearly thirty years after the Kodálys' visit to Santa Barbara, she was the only person who could still cherish the event as an unforgettable memory (Plate 12). The reliability of her recollections is proven by an article in English, written on the $25^{\text {th }}$ anniversary of Kodály's 1966 visit to America, published under Alan Strong's name but based heavily on information of Katinka Dániel's handwritten memoirs. ${ }^{36}$

The relevant information I received from Mrs Dániel is summarized here on the basis of the notes I took on the spot. I try to reproduce the phrases and words she used but do not aim at verbatim reconstruction. The conversation was conducted in Hungarian.

34. Albert Goldberg, "Ebell Event Honors Kodaly's Birthday,” Los Angeles Times Entertainment Section, Tuesday Morning, March 26, 1963, page C8.

35. "Kodály ünneplése Los Angelesben" [Celebrating Kodály in Los Angeles], newspaper clipping without the name of the author and the press organ, published after March 24, 1963.

36. Alan Strong, "Kodály in America: 1966," Kodály Envoy (Published by the Organization of American Kodály Educators) 18/1 (Summer 1991), 4-8. 
Plate 11 Ernő Dániel with members of the University of California at Santa Barbara Symphony Orchestra

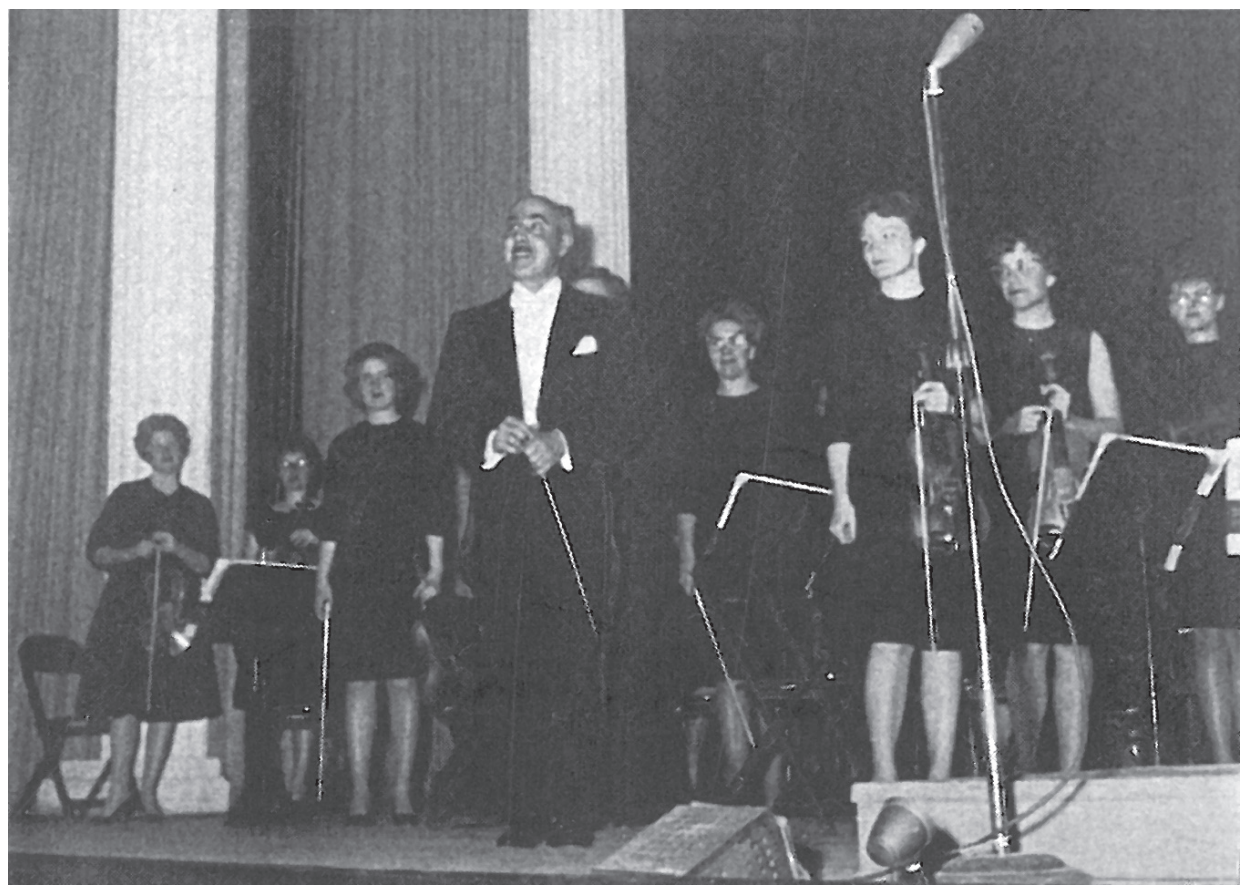

We got word that in August 1966 Kodály was to visit the United States invited to the ISME conference to be held in Interlochen, Michigan. We did not want to miss the opportunity to invite Kodály to Santa Barbara as well to a conference on musical education. Kodály failed to answer immediately to the invitation of my husband Ernő Dániel as he was not clear about the detailed schedule of his planned tour. It was only in summer when we returned from Monterey - where Ernő Dániel taught at a conductors' course organized by the American Symphony Orchestra League - that we found Kodály's positive telegram.

At that time, there was only a week left to organize the Santa Barbara conference set for August 2 and 3. That single week was only at our disposal to arrange for the Kodály concert following the conference, held in the Campbell Hall seating 900 at the university. Eventually so many people attended the concert that loudspeakers had to be installed for those who could not get in so that they could follow the performance. When Kodály and his wife entered the auditorium, the audience welcomed them with a tremendous standing ovation. After the official schedule, Kodály and his wife Sárika spent two weeks at our place. They arrived from San Francisco where Kodály had stumbled and fallen visiting a church and there were black and blue spots on his head and forehead. 
Plate 12 Photograph of Mrs Ernő Dániel and Zoltán Kodály, taken in August 1966

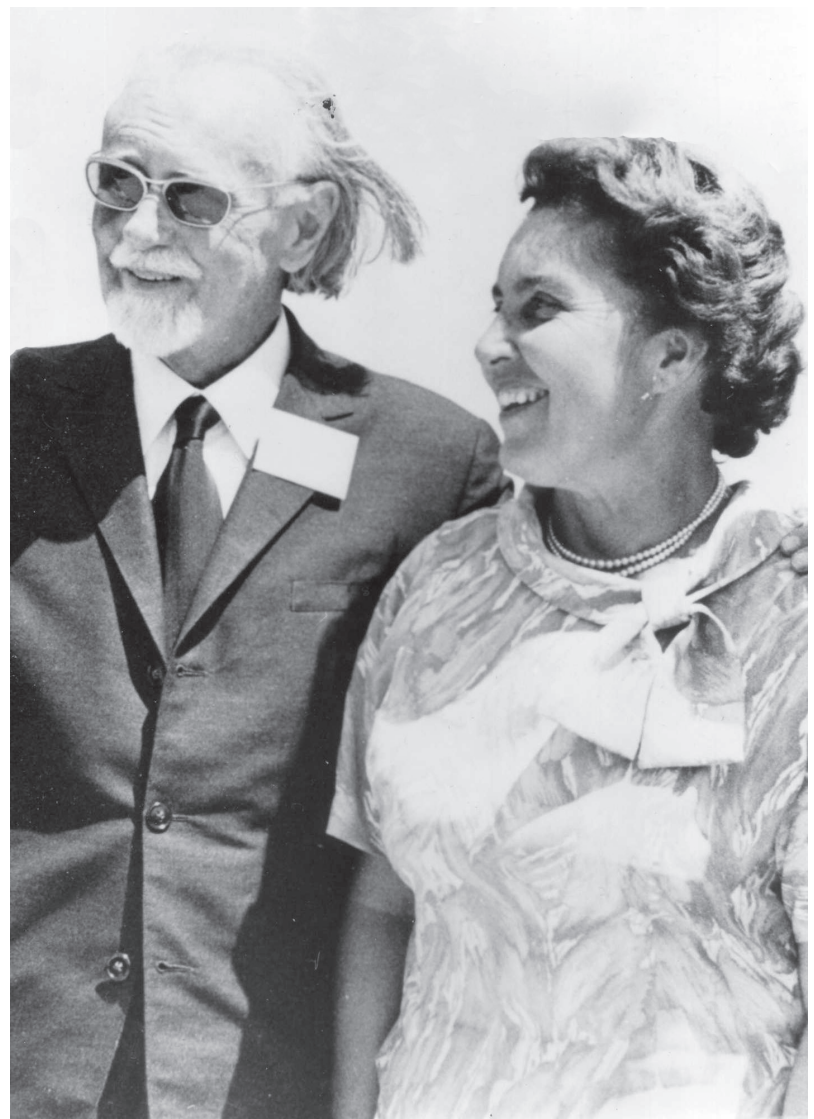

Ernő Dániel took him to see a doctor, but since no problem requiring medical care was found, we tried to speed up recovery by putting ice on. ${ }^{37}$

As head of the musical faculty of the university, Ernő Dániel had the possibility to make an interview with Kodály on the day before the conference. The idea was supported by chancellor Mr. Vernon I. Cheadle for the university leadership and upon his initiative, the interview was televised. We were aware that it was a last chance to preserve Kodály's freely delivered lecture in English on the fundamental questions of musical education. When preparing the questions of the interview, we took in consideration that Kodály, whose laconicism was proverbial, should get stimuli to which he would gladly respond. 
As a result of the thorough preparations and Dániel's profound knowledge of Hungarian and American musical education, an essential Kodály declaration was recorded on August 1 containing unique ideas in several respects. Kodály first voiced his view here that Bartók's piano cycle Mikrokosmos was not suited for the early phase of musical education. The video-recorded Kodály-Dániel interview is the only visual document that bequeaths to posterity Kodály's view on musical education in a comprehensive manner. ${ }^{38}$

An elegant program brochure of eight pages decorated with Hungarian motifs was printed for the conference (Plate 13a-c). The front cover showed the fullpage photo of Kodály leaning on an elbow, on the inside the place and title of the

Plate 13a-c Kodály's portrait and two pages of the program brochure for the conference "The Role of Music in Education: a Conference with Zoltán Kodály," held August 2-3, 1966
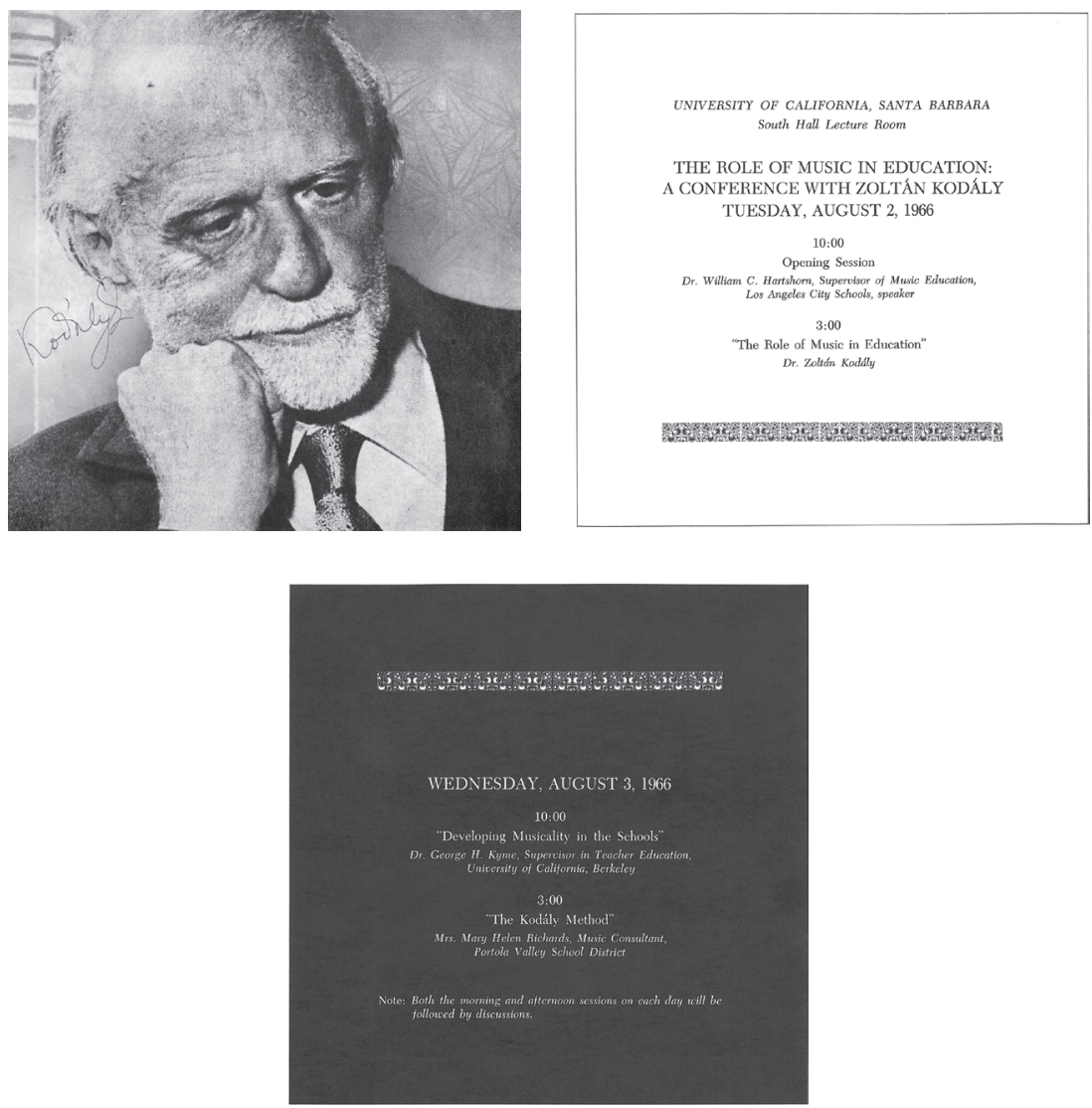

38. Ernő Dániel already suggested the publication of the text of the interview in a letter written on August 24, 1967 to Dr. David Gold, representing the research committee of the academic senate. However, the text was published as late as in 1986 by Richard Johnston. 
conference were indicated: University of California, Santa Barbara, South Hall Lecture Room and the title: "The Role of Music in Education: A Conference with Zoltán Kodály August 2 and 3, 1966".

Two lectures were held on the first day, both complemented with several comments. The speaker of the opening session at 10 a.m. was Dr. William C. Hartshorn, supervisor of musical education at the Los Angeles city schools, at 3 p.m. Zoltán Kodály took the rostrum. He presumably spoke freely, showing musical recordings. Kodály's speech is also mentioned in an article, dealing with both the conference and the concert, entitled "Búcsú Kodály Zoltántól" [Farewell to Zoltán Kodály] signed as "dr. H.P.K." and written, in fact, by the composer Károly Héthalmi Páth (1908-1995), a former student of the Budapest Music Academy who emigrated to the USA in 1956 where he worked as a church musician (see Appendix 3) ${ }^{39}$ Katinka Dániel registered that Kodály had brought a lot of audio recordings from Budapest to illustrate his speeches, which he later donated to her. She also mentioned that in his speech Kodály declared: "I never made a method."

The second day was similarly structured, with a speech in the morning and one in the afternoon. In the morning, Dr. George H. Kyme, supervisor of teacher education at the University of California, Berkeley, read his paper entitled "Developing Musicality in the Schools." In the afternoon Mary Helen Richards, music consultant of the Portola Valley School District presented a paper entitled "The Kodály Method." It is known that her knowledge of the theme was based on firsthand experience gained during her visits to Hungary. Several photos were taken at the Kodály conference (Plate 14).

The program of the festive concert held in the framework of the conference on August 2, from $8.30 \mathrm{pm}$ (Plate 15) and the selection of performers were determined by the extremely short one-week time available for the preparations. In the first half of the concert at the Campbell Hall chamber compositions were performed; in the second half the Missa brevis was locally premiered. The chamber section included the Sonata for Cello and Piano op. 4 and the Second String Quartet op. 10, performed by the same musicians: Alice and Gabor Rejtő and the Roth quartet, as they were on their repertoire since the Kodály concert in Los Angeles in 1963. However, the Duo for Violin and Cello op. 7 and the Seven Piano Pieces op. 11 were new compositions in the program. The performers of the latter two pieces, violinist Alice Schoenfeld and cellist Eleonore Schoenfeld and Dániel's disciple, pianist László Lak, added new names to the list of Kodály interpreters in California.

Missa brevis was performed by the Roger Wagner Chorale, bearing the name of the conductor. The choir was acknowledged by the American public as perfor-

39. I owe my thanks to Judit Neszlényi for this information. 
Plate 14 Photograph taken during the meeting chaired by Zoltán Kodály on the first day of the conference organized at the University of California, Santa Barbara

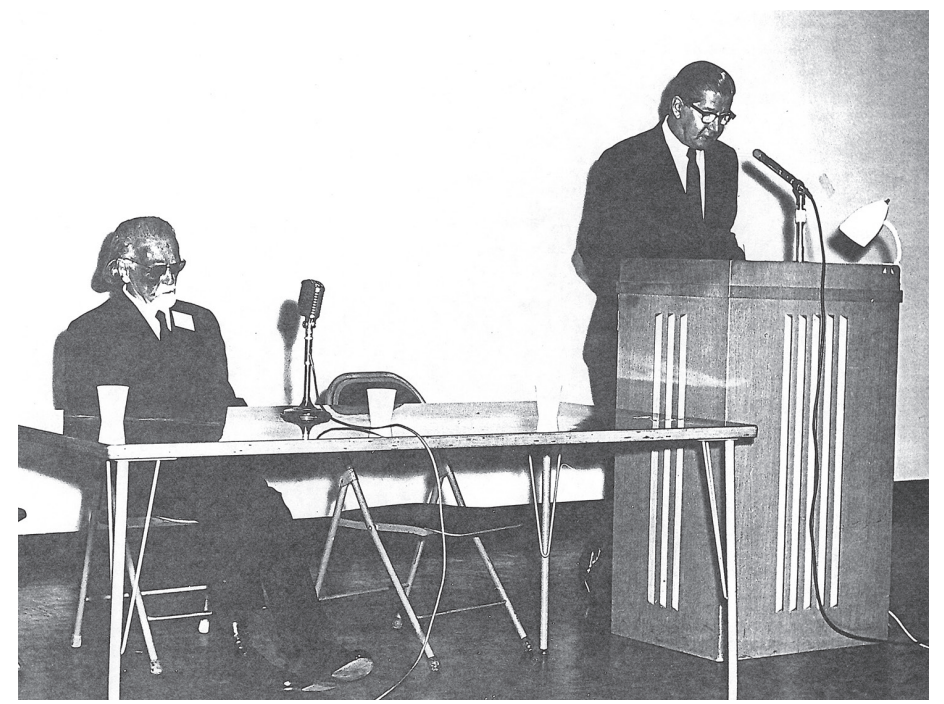

Plate 15 The program of the festive concert held in the framework of the conference on August 2, 1966

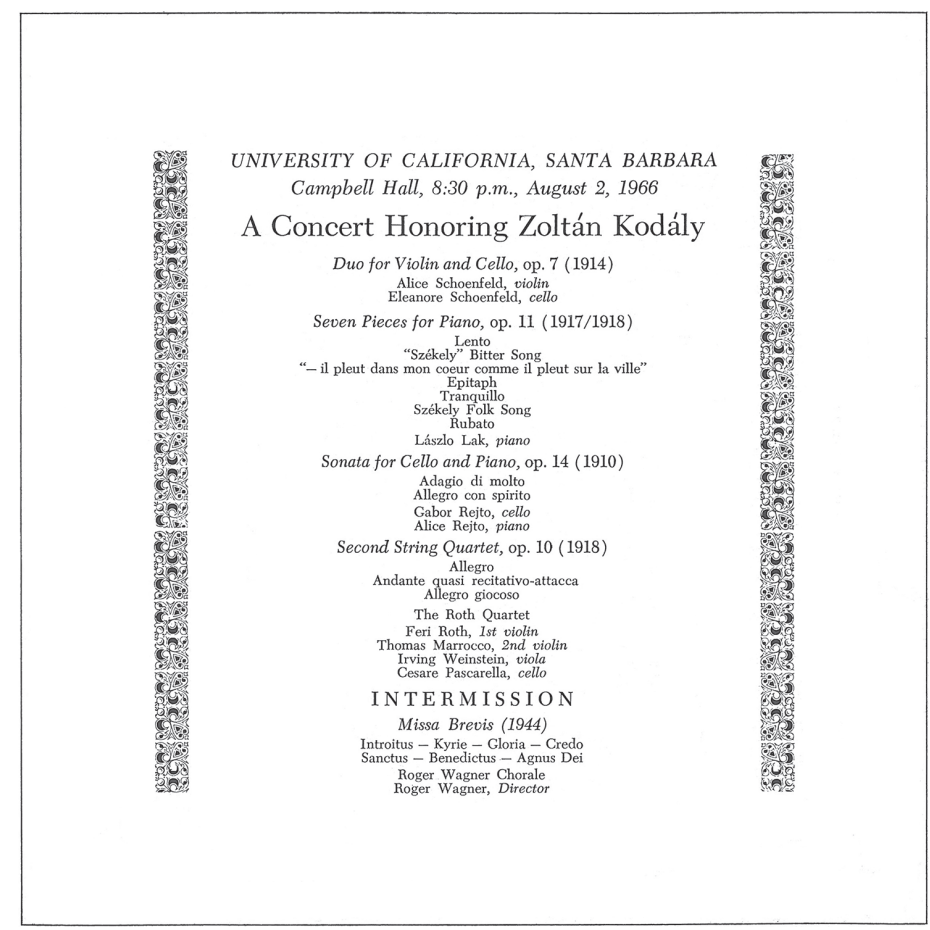


mers of internationally high standards. The entire performing team of the concert was labeled as "Top Southland Artists" in a press announcement of the concert. ${ }^{40}$

The official programs of the Kodálys' visit terminated on the conference day of August 3, but as mentioned earlier, private meetings continued. Katinka Dániel's recollections also mention a memorable episode of the convivial, intimate relationship with the Kodálys: singing bicinia with Sárika in the mornings in the room downstairs at the home of the Dániels.

To conclude my paper focused on the events and the documents connected to them, I have to propose some general observations. First of all, I must touch on the personal encounter of former students/musicians living in California with Kodály after a break of several decades, on the significance of their intellectual and artistic experiences. Two leading figures of the visit to Santa Barbara, composer Jenő Zádor and Ernő Dániel, recalled in a personal tone the essence of the moving encounter with Kodály on the fifth anniversary of his death in 1972. I quote the final conclusion of the visit in the wording of Ernő Dániel:

... Kodály's last visit to America (some months later he passed away) was a genuine triumphal march, one that few composers had ever experienced in a foreign country in their lifetime. Wherever he went, he was celebrated as if he were the only composer - just as he was celebrated wherever he went in Hungary - although in the United States lots of famous composers are living. The force of attraction emanating from Zoltán Kodály was best reflected by the mentioned conference. He accepted the invitation to Santa Barbara at the last moment, the date being in mid-summer, during the vacations. ... Still - and in spite of the last-minute notice - hundreds of well-known musical specialists came to attend. It was even more uplifting that all the artists involved in the festive concert on the occasion of the conference offered to participate for free, including one of America's best choirs, the Roger Wagner Chorale. The concert was an immense musical success; when Kodály and his wife entered the room, the audience stood up and gave a standing ovation to the great master for minutes. ${ }^{41}$

The documents from Santa Barbara and Kodály's statements published earlier deepen some insights by mutually reinforcing each other. It cannot be stressed enough that not only the former students now in their mature age were profoundly moved by the presence of Kodály - whom Kabalevsky labelled as the "soul" of

40. "Kodály Works to Be Played By Top Southland Artists," clipping of a press announcement for the concert on August 2, 1966. [without the name of the author and the forum].

41. Ernő Dániel, "Hódolat és tisztelet," 13. 
the Interlochen conference - but Kodály was also touched by his American experiences with similar intensity. The political situation of 1966 in which the reunions took place some two decades after the end of World War II was characterized by immense political, economic, and intellectual distances between East-Central Europe under Soviet domination and America. The differences rooted in the global situation, which can now be factually explored through the historical reconstructions, must have struck the Kodálys as they witnessed - coming from the atmosphere of intimidation at home - the inspiring climate characterized by the freedom of speech. The extensive intellectual impact and flood of information experienced by Kodály during the months of the free exchange of ideas were expressed directly in his declarations and interviews after his return. The accounts of the American tour also reveal that the intellectual conclusions of the American conferences brought about new differentiation and broadened horizon in Kodály's philosophical-pedagogical system of ideas.

Kodály's American experiences and the resultant thoughts - as can be gleaned from his subsequent statements - way exceeded the main theme of the visiting tour, the question of musical education. In his retrospections, he also discussed the American integration of the $20^{\text {th }}$-century émigré Hungarians, most conspicuously in relation to the preservation of the mother tongue. In his statement given to the Hungarian Radio with the title "Amerikai tapasztalatok" [American experiences] in autumn 1966, he spoke full of hope, with a more sincere optimism than ever earlier about the future connections of the new generations of Hungarian emigrants to their one-time homeland. His train of thought started out from the folksong, but it highlighted questions affecting the entire nation, in an increasingly general sense.

... The Hungarians living overseas ought somehow to be rallied around some common interest not only in music but in Hungary in general. Whenever I had the chance I told them they should not regard themselves as emigrants but as displaced parts of Hungary, belonging just as organically to the country as if they were living at home. There is hope that they won't forget the language completely. After the second generation, which was intent on forgetting the language to quickly learn English, the third generation tends to grow more interest in the country and the language. That should be nourished. ${ }^{42}$

This interpretation of the emigration is proof of Kodály's more deeply felt emotional and intellectual fellowship with the Hungarians who had left the country. Kodály's terminology, arising from a reinterpretation of the existence and circumstances of émigré Hungarians and taking the dissenters for a part of the unified nation, was undoubtedly the outcome of the emotional and intellectual communi- 
cation with them on an almost daily basis for several months in 1965 and $1966 .{ }^{43}$ The development of the emotional and intellectual aspects of Kodály's views on emigration can be traced on the chronology of his statements made in the 1960s, from the first "message" in 1962 to the above cited definitive formulation of emigrants as part of the nation. It must not be forgotten that Kodály worded his interpretation of the "displaced" members of the nation in the period of the incontestable validity of the Iron Curtain, in $1966 .{ }^{44}$ Kodály envisioned the situation of national unity and a future return implied by the phrasing at a time when there was no reality of even a distant reunion between those left at home and those who had left the country. Quite understandably, the contemporaries living in the world split irreversibly into two for decades regarded Kodály's statement as an artist's utopia with no tangential points with reality. Another lifetime had to pass before the political-geographic reshuffling of Europe sanctioned by the world-powers allowed for these ideas to be historically evaluated. What is more, from the end of the 1980 s to the first decade of the $21^{\text {st }}$ century another lifetime had passed before Kodály's view on the "displaced" has become a practically realizable goal in the conception of the unification of the nation, spanning over frontiers.

Were the only achievement of Kodály's American "triumphal march" the birth of the Kodályian insight of the essential unity between the nation and the emigrants in addition to the intellectual-artistic-pedagogical results and experiences, the latter statement of Kodály would also have to be registered as a historical milestone in the interpretation of $20^{\text {th }}$-century Hungarian emigration.

43. Kodály closed his speech and the following discussion on July 27, 1966 in Berkeley with the following thought: "I am also filled with great joy having heard so many good Hungarian words here. I realize that it is not a utopia what I am convinced of: that Hungarians living abroad organically belong to those at home. But they must also realize it." Zoltán Kodály, "Előadás és vita a Corvin Magyar Clubban” [Speech and debate in the Corvin Hungarian Club], in Visszatekintés 3, 191.

44. No similar views on emigration to Kodály's could be found in the 1960 s or even decades later in Hungarian cultural life. By way of an example, let me cite the concept of nation in an important Hungarian music historical compendium of the 1970s which almost "self-evidently" did not/could not regard the work of Hungarian composers outside the borders or in emigration as part of the contemporary Hungarian musical composition. There is no doubt that during the period in question when there was strict ban on the flow of scientific and artistic information, research had no access even to fragmentary sources on contemporary Hungarian artistic activity beyond the frontiers, consequently the survey of the Hungarian composition was limited to the artists living within Hungary. György Kroó's pioneering endeavor, the comprehensive review of contemporary Hungarian music published with the title 25 Years of Hungarian Composition published in 1971 and in an enlarged edition as 30 Years of Hungarian Composition in 1975, did not even aim to have a perspective beyond the borders. Being a compendium of music history on the theme, it was translated into German and English in the early 1980s. By that time, owing to a partial détente in intellectual-personal communicational possibilities, Hungarian composers outside the border and in emigration, respectively, interpreted the limitation of the nation concept in Kroó's work as their exclusion by the mother country. This is aptly revealed among others by the deep resentment emanating from a statement of Sándor Veress, an emigrant to Switzerland, made in the knowledge of the Kroó volumes. 


\section{Appendix \\ 1 \\ Lilly Erdődy's typewritten letter of invitation to Ernő Dániel \\ [English translation of the original in Hungarian]}

[Heading:] Hungarian in language / American in spirit / California Hungarian Theatre of the Air / Station KALI... 1430 on your dial / Every Sunday 2-4 P.M. / Featuring: Lilly Erdody / Director: Alfred Zlattner

Dr. Ernő Dániel

1416 Alta Vista

Santa Barbara, Calif.
3951 W. Seventh Street

Los Angeles S. California

January 30, 1963

Dear Maestro:

Unfortunately I have not had a chance to meet you in person, but I would like to turn to you with reference to my dear friend Miklós Rózsa.

Our radio is organizing a Kodály concert at Wilshire Ebell Theatre on 24 March for the benefit of the Los Angeles Music Center, under construction at the moment. I have managed to gain the support and participation of Miklós Rózsa and Gábor Rejtő. Both of them confirmed that you are an outstanding pianist as well. This has encouraged me to turn to you and ask you kindly to enhance the high standards of the concert with your participation. There will be two singers - once members of the Opera House - and the former prima ballerina and solo dancer of the Budapest Opera will dance the Recruitment Dance from Háry János. In addition, a children's choir will also perform.

I feel we are going to make amends with this concert because the Hungarians of America failed to duly celebrate Kodály's 80th birthday, and also because the local Hungarians ought to contribute to the costs of the Music Center.

In addition to the participating artists, the members of the patronizing committee include Dr. Tódor Kármán, the world-famous scholar of aeronautics, Dr. Joseph Kaplan, professor of UCLA (also of Hungarian origin), Hollywood producers Joe Pasternak and George Pal, Oszkár Beregi, Kálmán Pataky and many other great names.

I would gladly seek you out personally if you would kindly name an appropriate day.

I sincerely hope that our request will be given a hearing, the more so as it is our most ardent desire to have Hungarian art condingly represented in the concert to be attended by many Americans and advertised by American propaganda, too.

Yours sincerely, [manuscript signature]

Lilly Erdődy 


\section{2}

“Kodály Zoltán üzenete” [Zoltán Kodály's message]

[Clipping of a newspaper article without the name of the author, published on page 4 of the Los Angeles Hungarian newspaper

Szabadság around March 24, 1963$]^{45}$

LOS ANGELES - The Kodály concert organized by Lilly Erdődy was a frenetic success. Before reviewing it, let us present the Hungarian composer's message sent to the concert from Budapest. It reads:

Every nation has emigrants who try to make a better living outside the borders of their country either because they could not do so at home or because Macedonia was too narrow for them and they were irresistibly attracted by the wide world.

There is nothing wrong with that. A small country, a poor country is often incapable of nourishing all its sons at home. What's more, members of large and rich countries often live abroad, too.

But I cannot help spotting a difference between the emigrants of other countries and Hungarians. As if the bonds tying the Hungarians to the original homeland were weaker and broken more easily.

In the mouth and heart of Hungarians, especially those living in America, the Hungarian word, Hungarian song, the memory of the Hungarian landscape get faded more quickly. Their

45. Reproduced here with the kind permission of Mrs Kodály. The original text in Hungarian reads:

"LOS ANGELES. - Frenetikus siker jegyében folyt le a Kodály hangverseny Erdődy Lilly rendezésében. Még beszámolónk előtt hozzuk a nagy magyar zeneszerző Budapestről, a hangversenyre küldött üzenetét, amely így szól:

Minden nemzetnek vannak emigránsai, akik a haza határain kívül keresték boldogulásukat, vagy mert otthon nem találták meg, vagy csak mert szük volt nekik Macedónia, és vonzotta öket ellenállhatatlanul a nagyvilág.

Ez még nem volna baj. Kis ország, szegény ország, gyakran nem tudja otthon táplálni minden fiát. Sőt, nagy gazdag országok fiai is gyakran külföldön élnek.

De mintha különbséget látnék a magyar és más népek emigránsai közt. Mintha az óhazához kapcsolódó szálak gyengébbek lennének, könnyebben elszakadnának a magyaroknál, mint másoknál.

Különösen Amerikában élő magyarok szájában és szivében hamar elhalványul a magyar szó, magyar ének, szemében a magyar táj emléke. Gyermekeik alig, unokáik sehogysem beszélik a magyar nyelvet. Hogyan is maradhasson magyar, aki nem olvashatja eredetiben Petőfit, Jókait, Aranyt, Adyt?

Az új haza nyelvét kell tudni. Két nyelven egyformán jól tudni nehéz, nagy szellemi erőt kíván. Így hát sokan beletörődnek, hogy 15-20 év múlva nem kell már a magyar könyv, hírlap Amerikában, nem lesz, aki olvassa. Az a kérdés, lesznek-e elegen, akik nem törödnek bele?

A baj okát nemcsak a kivándorlókban keresem. Elsősorban az itthoni nevelés, iskolázás hibája, hogy nem épül fel bennük a külön magyar műveltségnek olyan tudatossága, amely életre szól, el nem homályosul és állandó tevékenységre késztet, hogy meg is tartsa elevenen, sőt, amerre jár, terjessze ismertesse.

Örömmel hallok minden olyan kísérletről, mint az Önöké, és kívánom több és maradandó eredménye legyen, mint eddigi tapasztalataim alapján remélni merem.

Üdvözlöm mindazokat, akik új hazájuk állampolgársági kötelességeivel össze tudják egyeztetni anyanyelvi müveltségük ápolását. Üdvözlöm Kármán Tódort, akinek édesapja alkotta tanterv nevelte bennünk annak tudatát, hogy minden műveltség csak nemzeti lehet, s csak ezen alapulhat széleskörű nemzetközi áttekintés. Üdvözlöm Beregi Oszkárt és Pataky Kálmánt, kiknek neve nem vesztett fényéből még élő kortársaik előtt.

Üdvözlöm mindazokat, kik szeretettel és megértéssel gondolnak régi hazánkra. Kodály Zoltán” 
children can hardly speak the Hungarian language; their grandchildren cannot speak at all. How can one remain Hungarian without being able to read Petőfi, Jókai, Arany, Ady in the original?

It is a must to know the language of the new homeland. It is hard to speak two languages equally well, it requires great mental strength. Therefore, many people reconcile themselves to the fact that in 15-20 years' time no Hungarian books, newspapers will be needed in America as there will be no one to read them. The question is: Will there be enough people who will refuse to resign themselves to that fact?

I do not blame the emigrants alone. It is the fault first of all of education system, of the schooling in Hungary that it does not built in them a life-long awareness of the unique Hungarian culture which will not get dimmed and will motivate them to keep it alive and even spread it wherever they go.

I am happy to hear about any initiative like yours, and I wish that it will have more numerous and more lasting results than I can hope for on the basis of my experiences so far.

I send my greetings to all who can adjust their constitutional obligations in their new country to the cultivation of their mother tongue. I am greeting Tódor Kármán, the curriculum designed by whose father inculcated in us the recognition that a culture could only be national culture, and only on this foundation can a broad international perspective be founded. I am greeting Oszkár Beregi and Kálmán Pataky, the radiation of whose names has not faded among their contemporaries still in life.

I am greeting all who think of their old homeland with affection and understanding.

Zoltán Kodály

3

dr. H.P.K. [dr. Héthalmi Páth Károly], "Búcsú Kodály Zoltántól”

[Farewell to Zoltán Kodály], Californiai Magyarság, August 12, 1966

[English translation of the original in Hungarian]

The two-day conference on education and gala concert organized by the University of California, Santa Barbara, in honor of Dr. Zoltán Kodály will remain unforgettable for us Hungarian teachers and our Hungarian compatriots interested in this highly educative and informative exchange of ideas, and also for the American teachers and educators who have an interest in the Hungarian method of teaching singing, worked out by Zoltán Kodály and his colleagues in Hungary with hard and persistent work over decades.

For the organization of this conference (A Conference with Zoltán Kodály August 2 and 3, 1966) - whose prospective influence on the emerging teaching of singing in American schools is still impossible to envision - not only the Americans but also we the American Hungarians and even our Hungarian homeland must be grateful to the former teacher of the Budapest Music Academy, now professor of the University of California, Santa Barbara, Dr. Ernö Dániel, the initiator, heart and soul, executor and motor of this beneficial meeting, so rich in musical events. [italics mine] 
The UCSB issued a beautiful 8-page program brochure - on the cover there is an artistic reproduction of a full-page Kodály portrait - with detailed presentation of all the events of the two-day conference. On both Tuesday and Wednesday there were two lectures by the most outstanding American educators such as Dr. William C. Hartshorn, Supervisor of Music Education, Los Angeles City Schools, Dr. George H. Kyme, Supervisor in Teacher Education, University of California, Berkeley; Mrs. Mary Helen Richards, Music Consultant, Portola Valley School District, whose presentation was particularly colorful and original, full of life so to speak, as she knows the Kodály-method from first-hand experience, having studied the methods of teaching singing in several schools in Budapest during her visit to Hungary. One of the speakers was Dr. Zoltán Kodály himself, presenting a lecture to over a hundred teachers with the title "The Role of Music in Education". This and every other presentation was followed by conversations with many questions raised and resulting in a rich exchange of ideas. In a short article like this there is no room to review at length every detail of the conference. Let me therefore mention the Tuesday gala evening held to full house in the concert hall of UCSB. Many people were left without tickets. The program - which gives a cross-section of the creative genius of Zoltán Kodály - could not have been compiled better and with a greater sensitivity at home in Hungary, either. The performers were also the most outstanding Hungarian and American musicians including Alice Schoenfeld (violin), Eleonore Schoenfeld (cello), Gábor Rejtő (cello) accompanied by Alice Rejtő (piano), the Róth Quartet, whose first violinist Dr. Feri Róth spoke in enthusiastic terms about Zoltán Kodály before their production. One of the finest manifestations of the homage to Kodály was the performance of Missa Brevis by Roger Wagner and his choir in such a profound, humane yet exalted form which, I think, was one of this ensemble's best achievements. During the unending applause, Wagner invited the composer to the stage. When Kodály's mythic figure appeared on the platform, the audience jumped to their feet to applaud him and pay the highest reverence to the Hungarian composer and educator, like in times of yore they honored another Hungarian genius, Ferenc Liszt. Only one person was missing from the stage who would have fitted the artistic standards most, the "most committed" musician who prepared and directed the entire festivity: Dr. Ernő Dániel, who remained modestly in the background and delegated his disciple László Lak to be the only piano soloist of the gala events; Lak received the Master's degree this summer and was a worthy representative of his master. In the intermission Kodály congratulated him on his fine performance.

Dr. Zoltán Kodály has left a great treasure for America: "The method of teaching singing in the school", "The Kodály Method," which in English translation will surely be of great use in the American schools. This is a strong strand which - together with other strands - will hopefully constitute a pillar in the structure of the bridge connecting America with Hungary. 